\title{
The role of place meanings in opposition to water-related infrastructure projects: the case of the Mactaquac Dam, New Brunswick, Canada
}

\author{
Kate H. Reilly ${ }^{1}$, Jan F. Adamowski ${ }^{1}$ and Kimberly John ${ }^{2}$
}

\begin{abstract}
Place attachment is often associated with opposition to infrastructure projects that change the characteristics of locations, including dam construction and removal. It has been suggested that in circumstances in which a project's perceived impacts are compatible with prevailing tangible place meanings, projects can be accepted even where local place attachment is strong. Here, we focus on the role of intangible place meanings in opposition to and acceptance of the potential removal of the Mactaquac Dam in New Brunswick, Canada. Based on interviews with 32 local stakeholders, we identified a range of place meanings related to community and personal identity. Continuity over time, community distinctiveness, and the role of various activities and experiences in developing identity were key themes. Those who wanted to retain the dam and those who wanted to remove the dam shared many meanings and only diverged in two community meanings. We suggest that conflict between the two groups may either be primarily based in different tangible meanings but escalated by the more emotional tangible meanings or that the two diverging community meanings were highly important. Further studies should investigate the specific role of intangible meanings in conflict where place attachment is strong.
\end{abstract}

Key Words: case study; conflict; dams; identity; place meaning

\section{INTRODUCTION}

End of life planning for large dams built during the early to mid-20th century in North America is becoming an important issue as those dams age and as removal is increasingly a viable option (Doyle et al. 2008). Dam removal generates considerable environmental, social, and economic change that affects stakeholder groups differently (Johnson and Graber 2002, Stanley and Doyle 2003, Brummer et al. 2017). The uneven distribution of costs and benefits created from those differential effects can result in the development of conflict among affected stakeholders (Sidaway 2005, Lejon et al. 2009, Perlaviciute and Steg 2014, Tonitto and Riha 2016, Reilly and Adamowski 2017a). Many conflicts over these and similar infrastructure projects become emotionally charged, which is thought to be due, at least partly, to disruptions to people's connections to locations that the project would affect (Buijs and Lawrence 2013, Devine-Wright 2013).

The concept of sense of place describes people's connections to a given locale and the values with which they imbue it (Tuan 1977). Although the definition of sense of place varies among fields, we define it as consisting of both attachment to a place and the meanings attributed to the place (Tuan 1977, Rickard and Stedman 2015, Stedman 2016, Masterson et al. 2017). Place attachment is the strength of a person's emotional bond with a location, which could be positive or negative (Low and Altman 1992, Manzo 2003, Stedman 2016). Place meanings define the nature of a place for a particular person, i.e., what type of place it is for them (Stedman 2016).

The meanings given to places and how people attach to places become highly relevant in making decisions about projects that may change the character of those places and thus have the potential to trigger highly emotional opposition and conflict among stakeholders (Davenport and Anderson 2005, Buijs and Lawrence 2013, Devine-Wright 2013). Numerous studies have investigated the relationship between strength of place attachment and the degree of project acceptance, particularly but not exclusively in the context of energy infrastructure projects, and have found both positive and negative correlations (Vorkinn and Riese 2001, Stedman 2002, Devine-Wright and Howes 2010, Devine-Wright 2011, 2013, Jacquet and Stedman 2014). The relationship between place attachment and management of water resources and environments has also been studied (Jorgensen and Stedman 2001, Stedman 2003, Davenport and Anderson 2005, Smith et al. 2011, Brehm et al. 2013).

To explain why attachment correlates positively with acceptance of some projects and negatively with acceptance of others, some studies suggest that place meanings may mediate the relationship. Among people with strong attachment to place, projects are accepted when there is a fit between the meanings attributed to a place and those given to the project, and vice versa (Stedman 2002, Devine-Wright and Howes 2010, Devine-Wright 2011). Although efforts have been made to identify the types of attachment associated with acceptance (Devine-Wright 2013), less attention has been paid to differentiating the variety of meanings, both tangible and intangible, among those who accept and those who oppose a project. Distinguishing the different forms of place meanings and their qualitative character, as opposed to the strength of place attachment, is helpful for informed decision making that contributes to sustaining locally important place meanings, as well as for understanding conflicts that may arise (Kil et al. 2014).

We used a decision on the future of the Mactaquac Dam in New Brunswick, Canada, to study the meanings stakeholders attributed to places in the dammed landscape and their association with acceptance of potential dam removal. We focused on removal because it constituted the greatest change to the status quo with the dam in operation. Earlier phases of this research addressed how stakeholders framed the effects of each option in terms of losses and gains and scale (Reilly and Adamowski 2017a,b), and their tangible, experiential place meanings were analyzed using the ecosystem services concept 
Fig. 1. Conceptual framework illustrating the relationship between place meanings and project support or opposition.

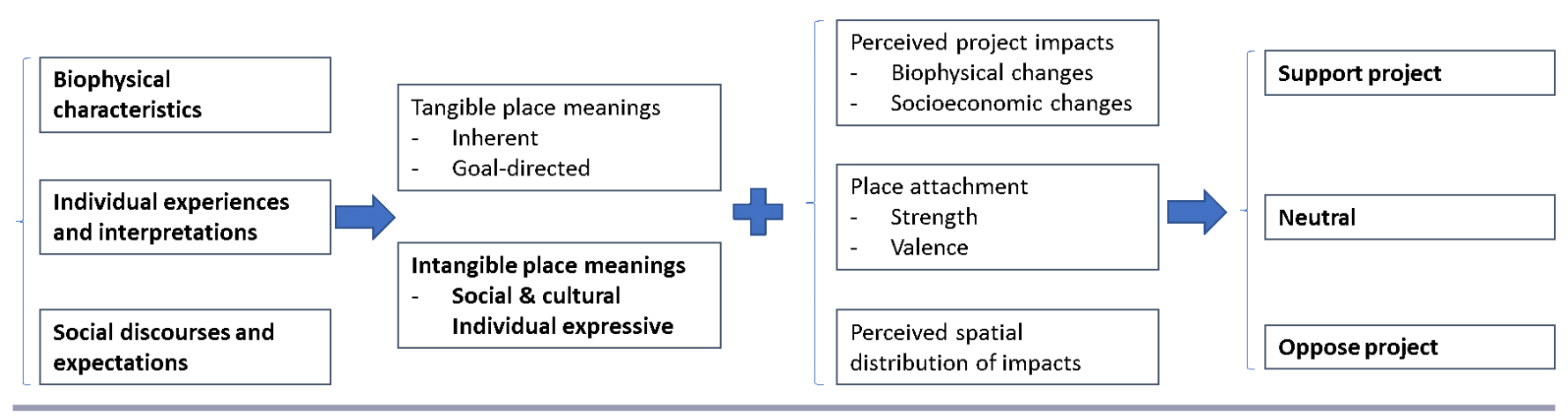

(Reilly et al. 2018). Here, therefore, we shift from addressing tangible place meanings, including experiential, economic, and ecological meanings, to intangible place meanings, including community identity and personal identity. We investigated the following research questions: (1) What are the intangible place meanings in terms of community and personal identity associated with the dammed river environment and how do they vary between people with different positions on the future of the dam? (2) How do individual and social meanings relate to the biophysical environment? (3) To what extent might intangible place meanings be affected by a change to the biophysical environment such as removal of the dam?

\section{CONCEPTUAL FRAMEWORK}

We developed a conceptual framework (Fig. 1) to link the intangible place meanings that individuals associated with the dammed river environment to other factors that may influence acceptance of dam removal. The framework draws on research on place meanings (Williams and Patterson 1999, Davenport and Anderson 2005, Smith et al. 2011, Kil et al. 2014) and research that conceptualizes project opposition as a desire to protect places (Stedman 2002, Devine-Wright 2009, Devine-Wright and Howes 2010, Anderson et al. 2013). Here, we focused on the concepts in bold (Fig. 1). Earlier phases of this research addressed tangible place meanings (Reilly and Adamowski 2017a, Reilly et al. 2018), perceptions of project impacts (Reilly and Adamowski 2017a), and perceptions of the spatial distribution of impacts (Reilly et al. 2018), and hence they were excluded from this study. The participants that supported and opposed dam removal were qualitatively assessed as being strongly and positively attached, so that aspect was not considered in detail here as a source of difference among stakeholder groups.

\section{Forms and development of place meanings}

People imbue locales with symbolic and evaluative meanings in a process that creates what is known as place, as defined by Tuan (1977:6): "What begins as undifferentiated space becomes place as we get to know it better and endow it with value." These meanings describe what type of place a location is and are the basis for the development of place attachment (Stedman et al. 2004, Beckley et al. 2007, Stedman 2008, Masterson et al. 2017). Because meanings are often specific to individuals, communities, and contexts, a variety of meanings can be attributed to any given location, which may lead to conflict if some are threatened (Williams and Patterson 1996, Davenport and Anderson 2005,
Beckley et al. 2007, Gunderson and Watson 2007, Anderson et al. 2013, Buijs and Lawrence 2013).

Many studies distinguish two main types of place meanings: tangible and intangible (Table 1; Williams and Patterson 1999, Davenport and Anderson 2005, Smith et al. 2011, Kil et al. 2014). Tangible meanings are defined as properties of the location and can therefore be viewed as objective, verifiable, and relatively functional. Intangible meanings are subjective and can be both personally and socially constructed (Davenport and Anderson 2005, Williams 2008, Kil et al. 2014). It is useful to differentiate the two categories in assessing the effects of a project to design effective conflict management approaches and to identify appropriate mitigation measures. Furthermore, perceived impacts on intangible meanings such as feeling that a place is home can render conflicts over proposed projects intensely emotional. However, it must be recognized that tangible and intangible meanings are often intertwined (Cheng et al. 2003). For example, Kil et al. (2014) found that tangible place meanings around ecology and economy are not very predictive of people's willingness to engage in participatory planning processes, but may be linked to the more significant intangible meanings of community and personal identity. Therefore, the two types of meaning can have different effects on decision-making processes, and thus, it is helpful to understand how they occur and interact.

Of the tangible meanings, some are inherent in the place itself and often take the form of aesthetic value attributed to certain biophysical features (Williams and Patterson 1999). Ecological meanings, i.e., valuing a location for its ecological components and processes that maintain ecological integrity, are also sometimes included in this category as objective qualities of the landscape (Smith et al. 2011, Kil et al. 2014). Others acknowledge, however, that both aesthetic and ecological value can be socially constructed within the boundaries of a location's biophysical features (Masterson et al. 2017).

The second type of tangible meanings involves how a place allows a person to meet their goals in terms of spending time there or having a particular experience (Williams and Patterson 1999, Smith et al. 2011). While these meanings vary among individuals, depending on what goals or needs they expect a place to meet, a location's biophysical features limit the range of possible activities; as an obvious example, hunting requires the presence of species that can be hunted (Williams and Patterson 1999, Stedman 2016, Masterson et al. 2017). These meanings can also 
Table 1. Summary of tangible and intangible place meanings and their associated components.

\begin{tabular}{|c|c|c|c|}
\hline Tangibility & $\begin{array}{l}\text { Meaning category (Williams and } \\
\text { Patterson 1999) }\end{array}$ & Subcomponents & References \\
\hline Tangible & Inherent meanings & $\begin{array}{l}\text { Appreciation of aesthetic appeal, support for } \\
\text { ecological integrity, supports valued ecosystem }\end{array}$ & $\begin{array}{l}\text { Davenport and Anderson (2005), } \\
\text { Smith et al. (2011), Kil et al. (2014) }\end{array}$ \\
\hline Tangible & Goal-directed meanings & $\begin{array}{l}\text { Enjoyment from experiences, economic meaning } \\
\text { or dependence }\end{array}$ & $\begin{array}{l}\text { Davenport and Anderson (2005), } \\
\text { Smith et al. (2011), Kil et al. (2014) }\end{array}$ \\
\hline Intangible & Community meanings & Family identity, community identity & Smith et al. (2011), Kil et al. (2014) \\
\hline Intangible & Individual expressive meanings & $\begin{array}{l}\text { Individual identity, place identity, expression of } \\
\text { the self }\end{array}$ & $\begin{array}{l}\text { Davenport and Anderson (2005), } \\
\text { Smith et al. (2011), Kil et al. (2014) }\end{array}$ \\
\hline
\end{tabular}

extend to a site providing the goods and services that contribute to an area's economy (Davenport and Anderson 2005, Smith et al. 2011, Kil et al. 2014).

Here, however, we focus on intangible meanings because they have been less studied in similar contexts than have tangible meanings and because earlier phases of this research focused on ecosystem services as a form of tangible place meanings (Reilly and Adamowski 2017a, Reilly et al. 2018). Such intangible meanings can take two forms. The first are community meanings, which are socially constructed and vary depending on the social and cultural context and its location in time and space, as well as on individuals' personal and family history (Williams and Patterson 1999, Kil et al. 2014). In constructing these meanings, a family, community, or social group defines its identity. Locations contribute to community identity development by supporting bonds between individuals and generations, being the setting for family memories and community history and being a source of pride (Kil et al. 2014). These meanings are shared within a social group, but different groups may have developed different meanings over time, which may compete (Williams and Patterson 1999).

The second type of intangible meanings is individual expressive meanings, which contribute to an individual's sense of identity (Williams and Patterson 1999). The contribution of place to personal identity is formed from a person's emotional, psychological, spiritual, and symbolic bond with that place (Williams and Patterson 1999, Kil et al. 2014). Both individual and community meanings are therefore intangible and subjective and are associated with a holistic sense of place that builds up over time (Williams and Patterson 1999, Kil et al. 2014).

Place meanings are thought to develop from a combination of the biophysical characteristics of a location, an individual's experiences and personal characteristics, and the discourses and expectations of the social context (Jacquet and Stedman 2014, Stedman 2016, Masterson et al. 2017). While there is considerable debate in the literature about the relative importance of these factors (Stedman 2003, Lewicka 2011, Jacquet and Stedman 2014), we assume that all of them contribute by shaping and constraining the possible meanings that can be attributed to a location at a given point in time (Stedman 2016, Masterson et al. 2017).

The biophysical environment contributes to place meanings both directly and indirectly. Its biophysical characteristics directly contribute to the type of description a place is given, such that a remote, wild forest can be labelled as wilderness; some researchers refer to this as providing the "raw material for meanings" (Jacquet and Stedman 2014, Stedman 2016, Masterson et al. 2017). For example, Stedman (2003) found that undeveloped lakes with clearer water and less public access were more likely to be given meaning as a place of escape than were those with extensive shoreline development. Indirectly, the biophysical environment limits how a person can interact with it, which influences the intangible meanings that can emerge from that interaction (Masterson et al. 2017). Therefore, if the biophysical environment changes, the range of possible social interactions and place meanings will also change (Davenport and Anderson 2005, Jacquet and Stedman 2014).

The social and cultural context of a location or a person also shapes their place meanings. Some researchers consider meanings to be mediated and sustained by ongoing social interactions in a location (Greider and Garkovich 1994, Stokowski 2002). At a higher level than individual interactions, power and authority can shape place meanings through communications, regulations, and cultural norms (Rickard and Stedman 2015, Masterson et al. 2017). For example, communications from national park services have been found to influence visitors' place meanings by teaching them what kind of place it is, in this case, a blend of human and natural elements (Rickard and Stedman 2015). Cultural norms also shape an individual's experiences in a place through social expectations of their role, for example, as an angler or hunter, and how they should behave (Masterson et al. 2017).

Within the constraints set by the biophysical environment and social and cultural context, people's direct and indirect interactions with a location give it meaning, and therefore, different modes of interaction can produce different meanings for the same setting (Jorgensen and Stedman 2001, 2006, Smith et al. 2011). Such modes of interaction could include permanent residence, seasonal residence, tourism, recreation, work, family history, and others (Stedman 2002, Kyle et al. 2004, Farnum et al. 2005, Smaldone et al. 2008). For example, a study of residents of a lake in Wisconsin, USA, found that permanent lakeshore residents gave the lake meaning as a neighborly community, whereas for seasonal residents, the same lake had meaning as an escape (Stedman 2002, 2008). Through a combination of different modes of interaction and personal characteristics, individuals develop a unique set of place meanings for a given social and biophysical context (Masterson et al. 2017).

\section{Contribution of place meanings to project acceptance or opposition}

Opposition to infrastructure projects that change the characteristics of a locale has been conceptualized as the desire to protect a person's sense of place, including both their attachment to it and the meanings with which they imbue it 
(Wester-Herber 2004, Devine-Wright 2009, Jacquet and Stedman 2014). Whether opposition occurs depends on whether a person perceives the changes a project induces as threatening their sense of place (Devine-Wright 2009, Jacquet and Stedman 2014).

It was initially thought that project opposition derived from strong attachment to place (Stedman 2002, Devine-Wright 2009). For example, an early study of public acceptance of a hydropower project in Norway found that strong place attachment was linked to opposition to the project (Vorkinn and Riese 2001). However, later studies found that individuals and social groups within an area affected by a project can have different responses, and negative correlations between place attachment and degree of project opposition are possible (Devine-Wright 2011). For example, strong place attachment was associated with support for a tidal energy project in Northern Ireland, which was interpreted as providing local employment, slowing economic decline, and as an "exciting novelty" (Devine-Wright 2011). It was therefore proposed that the relationship between place attachment and project acceptance is mediated by place meanings (Stedman 2002, Devine-Wright and Howes 2010, Devine-Wright 2011).

Opposition to a project is influenced by whether it is perceived to enhance or contradict prevailing place meanings (Stedman 2002, Devine-Wright and Howes 2010, Devine-Wright 2011, Anderson et al. 2013). For example, a study of a proposed wind farm in the United Kingdom found that place attachment was negatively correlated with project acceptance when the dominant place meaning was natural beauty that would be disrupted by the project (Devine-Wright and Howes 2010). Similarly, a study of plantation forestry in Australia found that those whose place meanings related to supporting lifestyles and amenity value viewed plantation forestry as risky, whereas those with meanings related to production saw it as both risky and of benefit (Anderson et al. 2013). However, individuals and social groups vary in the meanings they hold, their perceptions of the effects of a project, and their spatial location, leading to different responses (Anderson et al. 2013).

To determine whether a project is considered to support or interfere with place meanings, it is important to understand how affected people perceive its impacts on places (Devine-Wright 2009). Perceptions of change can arise from both a psychological process (Stedman 2002, Reilly and Adamowski 2017a) and from a social process, in which they are negotiated between people and with institutions (Devine-Wright 2009, Devine-Wright and Howes 2010). In either case, they can vary spatially based on uneven distribution of effects from the project and variation in prevailing meanings. We do not assess stakeholders' perceptions of change here because they have been analyzed for this case using cognitive frame theory in an earlier phase of research, which found that some stakeholders perceived dam removal as a loss and others as a gain, depending on their ecosystem service use (Reilly and Adamowski 2017a).

\section{STUDY AREA}

\section{Choice of case}

The Mactaquac Dam, a large hydropower dam on the Saint John River, New Brunswick, Canada, was chosen as our case study (Fig. 2). It was selected because both the river in its predammed state and the reservoir created by the construction of the dam, known locally as the Mactaquac headpond, are of high local importance. Construction of the dam considerably changed the morphology of the river upstream of the dam from a shallow river with several islands to a deep, slow-flowing reservoir. Despite local opposition to its construction (Bourgoin 2013), many people have adapted to its presence and now demonstrate attachment to it and the headpond (Keilty et al. 2016, Sherren et al. 2016). However, others would like to see the dam removed and the original river morphology and way of life restored (Reilly and Adamowski $2017 a$ ). Therefore, the case provides an opportunity to explore how place meanings vary among people with diverging views on the possibility of dam removal.

\section{The Mactaquac Dam and its influence on the Saint John River and its population}

The Mactaquac Dam has been in operation since 1968 and currently supplies approximately $12 \%$ of New Brunswick's electricity (NB Power 2016). It was built to provide energy for the economic development and industrialization of the province (Bourgoin 2013). A park close to the dam, a historical museum of original buildings relocated for the creation of the headpond, and a pulp and paper mill were also built as part of an associated rural development project (Si 1993, Bourgoin 2013).

Fig. 2. Location of the study area in Canada (A) and New Brunswick (B). (C) Boundaries of the study area (purple line) were defined as a 5000-m buffer around the reach of the river most hydrologically affected by the dam and its tributaries (approximately Hartland to Oromocto). Produced in ArcGIS 10.4 (ESRI 2016) and contains information licensed under the GeoNB Open Data Licence and under the Open Government Licence - Canada, as well as data from Natural Earth. Source: Reilly et al. (2018).
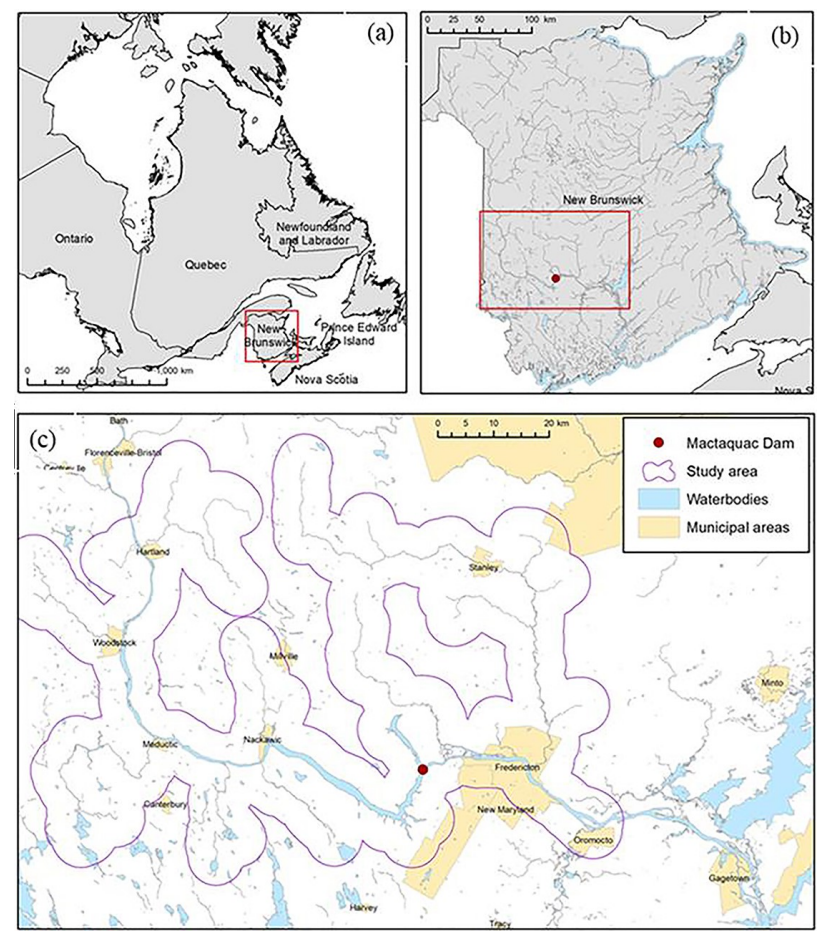
Productive fertile farmland and churches and graveyards were flooded to create the headpond, and 900-1100 people (estimates vary) were displaced (Si 1993, Bourgoin 2013). The residents' objections focused on the impacts of these material losses on their aesthetic, cultural, and historic attachments to the river. The loss of churches and graveyards represented both a rupturing of the connection to previous generations and, more generally, to the area's British settler heritage (Bourgoin 2013). These arguments were labeled "sentimental" by the dam planners, and thus, were easily dismissed (Kenny and Secord 2010, Bourgoin 2013).

Now, the headpond is a popular local destination for recreational activities (Fig. 3), including boating and fishing, which support local businesses and tourism (Dillon Consulting 2016, Stantec 2016, Reilly and Adamowski 2017a). Numerous other ecosystem services are important, including the intrinsic value of ecosystems and aesthetic appeal (Reilly and Adamowski 2017a, Reilly et al. 2018). However, the dam forms an impassable barrier to migrating fish, including the economically valuable Atlantic salmon, whose population has declined in recent years (Stantec 2016). The river flow downstream of the dam fluctuates by $1 \mathrm{~m}$ on a daily basis as water is released through the dam in response to energy demands. This is a stressor to aquatic species in this reach of the river and complicates its recreational use. Overall, therefore, the dam has had both advantages and disadvantages for the area and the province.

Fig. 3. Mactaquac headpond, viewed from the town of Nackawic. Photo: K. Reilly.

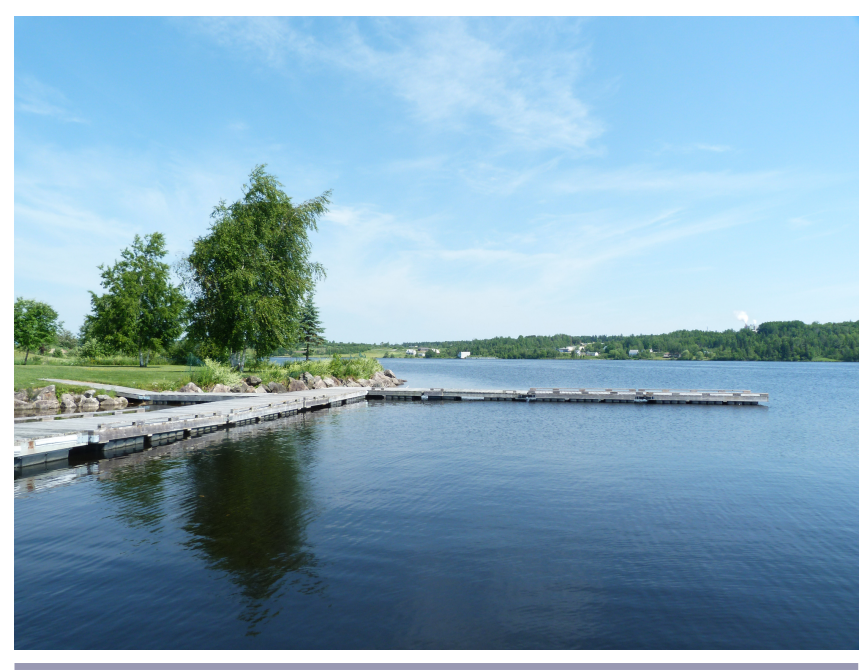

At the time of study, New Brunswick Power (NB Power), who owns the dam, was in the process of evaluating options for the dam's end of life, which was moved forward because of a structural problem. The three options under consideration were: to rebuild the affected concrete electricity generating structures, which would allow the dam to continue functioning as a hydropower producer and maintain the headpond; to retain the earthen dam that maintains the headpond and decommission the electricity generating structures; and to remove the dam entirely and return the river to its free-flowing state (NB Power 2016). At the time of data collection, the environmental and social impacts of each of these options had been reviewed and communicated to the public. A consultation process was underway, in which NB Power requested submissions and responses to an online survey from New Brunswickers and held community meetings in the affected reach of the river (NATIONAL and CRA 2016).

The decision on the dam's future was controversial. The outcomes of NB Power's consultation process, reported after field work was completed, revealed that although a majority of respondents preferred to retain the dam, others wanted to remove it (NB Power 2015, NATIONAL and CRA 2016; NB Power, https://www. nbpower.com/blog/en/posts/2015/november/your-feedback-mactaquacopen-houses/). The strong local interest and divergent opinions about the options for the dam's future made the case an ideal opportunity to study how sense of place in and around a river environment varies among stakeholders with different opinions about a possible change to that environment. The dam is one of the largest in the world to ever be considered for removal, making it an important test case for other large dams reaching the end of their lifespans.

Since the data collection was completed, NB Power decided to enhance maintenance, replace critical components, and install a fish ladder to allow the dam to reach its originally planned 100year lifespan (NB Power 2017). This essentially preserves the status quo, but a similar debate will have to take place in 30 years' time when the decision has to be made again. Therefore, this study will still be useful both as a reference for the future decisionmaking process and in guiding management of the dammed river in the present.

\section{METHODS}

\section{Sampling and data collection}

We used a qualitative approach to identify the range of locally specific place meanings present in the study area (Davenport and Anderson 2005, Devine-Wright 2011). This enabled us to understand people's reasons for their deeply personal relationships with places and to identify how a potential change to the physical space would affect their sense of place (Gunderson and Watson 2007). We used qualitative semistructured interviews, which were combined with a participatory mapping exercise, the results of which are reported by Reilly et al. (2018).

To select interviewees, we used nonproportional quota sampling to understand how sense of place varies between individuals with different characteristics (Gunderson and Watson 2007). We aimed to include the main interest groups, as well as interviewees located throughout the affected area (Fig. 2). We invited representatives from a list of stakeholder groups in the study area that was developed in an earlier phase of the study (Reilly and Adamowski 2017a) and contacted other people recommended to us in a snowball sampling approach. We continued inviting stakeholders and conducting interviews until no new themes were introduced in the interviews, i.e., theoretical saturation was reached (Strauss and Corbin 1998). The final sample included 32 individuals, which included three family members of invited interviewees, of which 12 had participated in the earlier phase. Interviewees comprised small business owners; representatives of environmental and watershed groups, municipalities, recreation groups, and heritage groups; students; farmers; and upstream and downstream residents. Notable groups that were missing included Maliseet First Nations and industry, who had declined to participate in an earlier phase of the study. 
The interviews began with questions on what the participants thought should happen to the dam and why, and how they thought each option for the dam would affect them. We then proceeded with a series of questions on places in, near, or around the river within the study area that were important to them (Appendix 1). We first asked participants to identify places that were important according to their own criteria. We then used prompts on cultural ecosystem services adapted from an interview protocol designed by Klain and Chan (2012) and Gould et al. (2015), which used broad, plain-language questions to elicit use of the ecosystem services that were identified as locally important in an earlier phase of the study (Reilly and Adamowski 2017a; Appendix 1). We chose this protocol to encourage participants to reflect on a range of ways in which the environment and specific locations may be important for them. For each question, we asked what was important to the participant about each place and why they liked it. We used closed probing questions as needed to follow up on ideas and check understanding (Patton 2005, Gould et al. 2015). The participants were also asked to mark on a map the places they identified, the results of which are reported in Reilly et al. (2018).

The interviews lasted between 40 and 90 min and took place in locations of participants' choosing, including their home, workplace, and local cafes. We conducted all interviews between May and June 2016.

\section{Qualitative data analysis}

All recorded interviews were transcribed, and the main themes were collated into a short summary document, which was returned to participants to check our interpretation. Nine participants confirmed that the summaries were accurate, and five requested changes to minor details; the remainder did not respond.

We used an iterative process of descriptive coding to identify the place meanings associated with the locations mapped and with the study area in its entirety (Miles et al. 2013). To identify meanings, we looked for pieces of data that described how a person valued a place and then coded the data according to those values.

Using this coded dataset, we removed all tangible place meanings (Table 1), including all references to ecology, aesthetics, economic value, and recreational experiences, unless they were linked to community or personal identities in some way. We retained all intangible meanings, i.e., community meanings and individual expressive meanings. For example, if a person expressed that being able to walk in a rare and biodiverse forest helped them feel fulfilled, the idea of fulfilment was retained as an intangible meaning.

We then proceeded with further iterations of coding the intangible meanings, which involved entering each code into a codebook with a description and example, then comparing codes and refining the coding and codebook (Appendix 2). We grouped codes into subcategories of meanings (or pattern codes; Miles et al. 2013) using an inductive process of looking for similarities and differences between codes. Lastly, we sorted the meanings subcategories into the two broad categories of community meanings and individual expressive meanings (Table 1).

We then summarized the coded data into several display tables organized by participants' roles and their position on the dam
(Miles et al. 2013). The tables had a line for each participant and a column for each meaning, grouped into the meaning subcategories. Each participant's intangible place meanings were entered into the corresponding cell with a representative example from the coded data. This allowed us to compare the types of meanings within categories, between individual participants, and between the groups of participants.

\section{RESULTS}

Intangible place meanings and their variation among people We present here the range of community and personal identity meanings, illustrated with quotations from the participants' interviews.

\section{Community identity meanings}

Community identity meanings focused on individual villages or towns, the region, or the province. They were grouped into the following subcategories: (1) community based around shared lifestyle and livelihood, (2) the place is like no other, (3) connections with past generations, (4) connections with future generations, (5) history is close to the present, and (6) the river and nature define the community.

The first subcategory included reflections on what maintains a community, such as shared recreation and celebrations and sufficient population and jobs, specifically focused on the role of the headpond in maintaining these links.

The dam is essential for our pulp industry here. The community was created too from this place [the mill]. Participant 04

Subcategory 2 focused on the distinctiveness of communities and the region as a key component of identity by differentiating them from other areas and therefore viewing them as special.

It's one of the premier boating areas in the province also. Because you're not running up on sandbars or anything. So it's recognized worldwide for its boating recreation.Participant 40

Maintaining what was done in the past (subcategory 3 ) and what should continue into the future (subcategory 4) were important in defining a community by emphasizing its continuity over time. For example, it was important for many to retain connections with the past by retaining places of family heritage or by sharing the same experiences as previous generations. The need to maintain opportunities to have those experiences in the future was also emphasized.

What would happen is that whole boating recreational thing would disappear. So kids in the future wouldn't get a chance to experience what kids experience today. Participant 01

The past was also important in terms of its traces that can still be seen today, which act as reminders of the region's history (subcategory 5).
At Kings Landing, there are homes there that I visited as a child that were actually homes that families that I knew were living in here in the community. And when the dam came through, those homes would have been destroyed, so they were moved to Kings Landing. And that's just part of the heritage of this place. - Participant $05 \mathrm{~W}$ 
Lastly, many participants emphasized the importance of the river for the identity of various villages or towns, regions, the province, and the Maliseet First Nation (subcategory 6). They discussed the importance of the river in the history of the settlements in the province and how the presence of the river continues to define the area and its people. In particular, the importance of the river to the Maliseet people was highlighted.

To be Maliseet means to be Wolastoqiyik. People of the beautiful river. Like, that's the people. So that's beyond significant. - Participant 37

\section{Personal identity meanings}

The personal identity meanings had some thematic similarities with the community meanings, including the importance of continuity between past, present, and future, and the importance of activities and experiences in contributing to identity. They were grouped into several subcategories: (1) the place enables accomplishments, (2) it inspires emotions, (3) it builds and sustains relationships, (4) it feels like home, (5) it is who I am, (6) it ensures continuity in my life, (7) I know it, and (8) it does not define me.

For individuals, those activities produced a sense of accomplishment and stimulated emotions, both of which were considered important for a person's idea of who they are (subcategories 1 and 2). For example, several participants mentioned that places in and around the river had taught them what they know, built their confidence, and enabled their life's work.

\section{It was poor land, but we did land improvements and we} farm it. - Participant 32

For many people it was specifically the water or nature in particular places that inspired emotions or made them feel peaceful.

Why am I drawn to water... I don't know [...]. It's just one of those calming, soothing things to me. - Participant 39

A very commonly cited meaning involved the contribution of places, activities, and shared experiences to forming and maintaining relationships with others (subcategory 3 ).

Because of [...] the fact that we use the river, we've a larger circle of friends than some of my sisters who have lived here all their lives. - Participant $01 \mathrm{~W}$

Many participants described either water in general or the river itself as feeling like home and inspiring a sense of belonging (subcategory 4).

I know it's from the activities that I do and I could do those activities somewhere else. But I think it's not just the activities, it's [the river is] like your home. Participant 22

Others incorporated the river and places around it directly into their sense of who they are by feeling rooted in that place through being born there or it being where their ancestors were from, or simply feeling that the river is part of them (subcategory 5).
I identify with this, this has made me who I am certainly, being on this river and growing up right there and working and living on it. - Participant 36

Memories and stories from earlier phases of people's lives were also important in maintaining a sense of continuity, including, for some, past the end of their lives (subcategory 6). These stories and memories helped people develop a sense of belonging.

When I first came in sight of the Saint John up around Hartland, just all of a sudden I felt where I belonged again. I just reconnected at some level with the river. Participant 44

The accumulation of time spent in the area and activities experienced there allowed some participants to develop a deep knowledge of locales and how they behaved (subcategory 7).

Living beside the headpond for 55 years, you even know the yard lights. When you leave Nackawic and come down that headpond, you can tell where you are by the yard lights, and like whether you're in Kings Landing or whether it's the yard light of the gas station in Prince William. - Participant 40

Lastly, for some participants, interactions with the river over a period of time may have been enjoyable but did not contribute to their identity (subcategory 8 ).

But as far as would I send somebody to go see this or go see that, something that I would identify with, nope. Participant 30

While there was individual variation in which intangible place meanings were present, there were few obvious patterns between the participants who preferred to retain the dam ("retainers") and those who preferred to remove it ("removers"). However, the majority of removers did not refer to the community being defined by shared livelihoods and lifestyles (subcategory 1). Although retainers expressed meanings in subcategory 6 about the river and nature defining the community, it was less common than among the removers. There were both retainers and removers in all age groups interviewed.

\section{Relationships between intangible meanings and the biophysical environment}

The intangible meanings demonstrated by participants were closely related to the biophysical environment. This may be expected because participants were asked to focus on important places in, near, or around the river, which would have led them to consider the biophysical environment in their answers. Despite this, we investigated the range of ways in which the biophysical environment contributed to intangible meanings.

In many cases, the biophysical environment allowed or promoted experiences to which intangible meanings are attached, whether for community identity or personal identity. For example, many of the economic activities in communities, such as tourism, farming, and the paper and pulp mill, directly rely on certain biophysical conditions. This is considered a goal-directed tangible meaning (Table 1) related to economic importance. However, the role of these activities in sustaining and defining the community then is considered an intangible meaning. 
That's what the community's built of, is people that have moved to Mactaquac to work at Mactaquac Dam and build their life around the headpond and Mactaquac Dam. - Participant 40

Therefore, in this case, the biophysical environment relates to intangible meanings with goal-directed tangible meanings as an intermediary.

The community's distinctiveness was closely related to the rarity of elements of the biophysical environment.

People that come from away, they could not believe that we're on a river with hardly any boats. But lots of eagles and stuff like that. So that is again starting to get this river, as it is now, more recognized. - Participant $05 \mathrm{~W}$

In this case, the relationship between the biophysical environment and intangible meanings is mediated by inherent tangible meanings, notably its ecological importance (Table 1).

However, while the majority of links between the biophysical environment and intangible meanings was mediated by tangible meanings, this was not the case for all. Elements of the biophysical environment were also considered a physical reminder of the community's history and its past identity.

[Kings Landing Historical Museum] would be a prime location of interest for anybody coming here and wanting to know about how people lived in New Brunswick back in the 1800s. I think it's really, really a significant, a significant site. - Participant 43

\section{DISCUSSION}

\section{Role of intangible meanings in opposition or support of dam removal}

Our results demonstrate the wide range and importance of intangible place meanings in the study area. For many of the participants, places in and around the dammed river environment were highly significant in determining their community's identity and their own personal identity. Most individuals held multiple place meanings, and the participant group as a whole did not hold one common place meaning.

While it could be expected that intangible meanings linked to recreational, economic, and ecological tangible meanings would be affected if changes to the biophysical environment altered the economy, ecology, or recreational opportunities, it is less clear how such changes would affect those intangible meanings that are less directly linked to tangible meanings. Some intangible meanings identified in the study were associated with places that no longer have the biophysical characteristics that were the source of the meaning, suggesting that the meaning can remain in place when the characteristics change. Two notable examples are the value attributed to salmon pools, which were present in several locations before the dam was built but have now been flooded, and Fort Meductic, a site of historical importance that is also now underwater. Similarly, other studies of retainers in the area showed that individuals who had had deep emotional connections to the undammed river were able to adapt to appreciate the dam in place (Keilty et al. 2016, Sherren et al. 2016). However, this does not mean that all identified intangible meanings would survive this transition or would be perceived to survive this transition. Indeed, some participants explicitly stated that they would not feel the same way if the headpond was no longer there. This issue deserves further study, possibly in the form of a longitudinal study that investigates place meanings both before and after a change in biophysical conditions.

The lack of considerable differences in intangible meanings between the participants who would accept or support dam removal and those who would oppose it was somewhat surprising. It could have been expected that the two groups would have different sets of meanings that were perceived as compatible or incompatible, respectively, with dam removal. Several other studies of the role of place meanings in conflict around natural resource management found that conflict occurs between stakeholders with strong place attachment but different place meanings, which would be affected differently by management decisions (Stedman 2003, Anderson et al. 2013, Masterson et al. 2017). Others found that opposition to energy projects occurred among those who held place meanings that were perceived to be incompatible with the impacts of the project (Smith et al. 2011, Jacquet and Stedman 2014). Therefore, we would have expected to see a clear difference in meanings between those that supported retaining the dam and those that supported removing it.

There are several possible explanations for the inconsistency between our finding of little difference between individuals holding different positions on the dam's future and studies of other similar decisions. First, we suggest that in some cases, tangible place meanings may be more important or easier for participants to assess as compatible with a project than intangible meanings. We identified here that tangible meanings may form the link between the biophysical environment, which would be altered by dam removal, and the intangible meanings that can lead to more emotional responses to decision making. Furthermore, earlier phases of this study found clear differences in tangible meanings, expressed using ecosystem services, between the two groups (Reilly and Adamowski 2017a, Reilly et al. 2018). This result is consistent with other studies that found that perceived compatibility of a project with aesthetic appeal, ecological meanings, and economic meanings was related to whether stakeholders oppose or accept a project (Devine-Wright and Howes 2010, Devine-Wright 2011, Anderson et al. 2013). Therefore, it may be the case that stakeholders diverge in their tangible place meanings, leading them to assess compatibility differently, but that those different tangible place meanings contribute to the formation of similar intangible meanings. That these intangible meanings are linked to different tangible meanings and different features of the biophysical environment means that individuals holding the same intangible meanings may respond very differently to a project perceived to change the characteristics of a location. Similarly, the connection with intangible meanings can explain why mitigating the loss of tangible meanings may be insufficient to win support for a project. This approach that focuses on the details of place meanings, including the biophysical features they are linked to, and a person's history and perceived or desired future, reveals how a project may change people's relationship to place in a way that may not be reflected in their degree of attachment.

Another possible explanation relates to the one identified difference in community meanings: that the community being 
defined by shared livelihoods and lifestyles was more common among retainers, and the community being defined by the river and nature was more common among removers. Both of these meanings were commonly cited among individuals in the respective groups, and many retainers additionally frequently mentioned their desire to preserve the current opportunities and way of life for future generations. Therefore, although our study was not designed to assess the relative significance of meanings, this difference between the groups is likely to be important. If that were indeed the case, the two groups would then differ in at least one form of intangible meaning, several tangible meanings (Reilly et al. 2018), and their perceptions of the project's impacts. We recommend that further research with a larger sample size should aim to explore the relative importance of the shared and contested meanings. For example, a Q methodology exercise that involves ranking the importance of the various meanings identified here could be conducted (Anderson et al. 2013).

The existence of subjective and emotional place meanings may have the potential to heighten emotions in general around the decision and exacerbate conflict arising from diverging tangible meanings (Cheng et al. 2003, Buijs and Lawrence 2013). Emotional responses to an issue can escalate conflict and produce a vicious cycle of increasing emotion worsening the conflict, which in turn increases emotion (Buijs and Lawrence 2013, Sandström et al. 2013). In particular, intangible meanings are based around identity, both at personal and community levels. People can respond strongly when they feel an infrastructure project threatens their identity (Wondolleck et al. 2003, Gray 2004). Emotion may also shift the balance of power in a conflict: those parties who respond emotionally can find themselves delegitimized on the basis that they are not engaging in a constructive manner (Buijs et al. 2011, Buijs and Lawrence 2013).

To take account of the potential for divergence in meanings and for the presence of intangible meanings to escalate conflict, we therefore suggest that the meanings-mediated model by which place attachment influences opposition to projects (DevineWright 2009, 2011) could benefit from tangible and intangible meanings being differentiated. Tangible meanings are more clearly linked to the biophysical conditions that would be changed by an infrastructure project and, therefore, may be more likely to be assessed as compatible or incompatible with the project. It may be more challenging for a stakeholder to determine how a project would affect intangible meanings directly, but if they are affected by the project via tangible meanings, conflict or opposition may be heightened. However, our study was only intended to be exploratory; therefore, the relevance of a differentiated model should be further investigated in other contrasting cases and tested in quantitative studies of randomly sampled stakeholders.

\section{Decision making sensitive to intangible place meanings}

People's relationships with the dammed river environment cannot be described with one single place meaning. For each individual, and for the participants collectively, each place is important and valued in several ways. It is therefore impractical for decision makers to attempt to preserve a singular sense of place when considering projects that would alter certain characteristics of the locale (Yung et al. 2003, Nash et al. 2010). Indeed, efforts to do so may risk excluding other equally important place meanings and, by extension, the people who hold them (Nash et al. 2010, Masterson et al. 2017).
Decision makers should therefore aim to be sensitive to the multiple meanings that people hold in the affected area (Davenport and Anderson 2005). First, it is important to understand the place meanings that prevail within the affected area, including how they are complementary and conflicting (Yung et al. 2003). The act of gathering information specifically on the multiple dimensions of place meanings, including taking into account the more emotional and subjective intangible meanings, can help to build trust between stakeholders and decision makers (Farnum et al. 2005). This procedure can ultimately be expanded into a participatory decision-making process focused on place, which has been found to allow a greater range of stakeholders to be involved and perspectives to be elicited then nonplace-based processes (Cheng et al. 2003, Wheeler et al. 2016).

Second, understanding place meanings can help to understand conflicts around potential dam removals and other similar infrastructure questions (Stedman 2008). For example, in a study of a proposed development and the conflict it sparked over land use, Nash et al. (2010) revealed that the site was attributed with a range of symbolic and socio-political meanings, some of which were shared and some contested, that were psychologically important. Our study similarly identified that people associated the river with meanings that were highly socially and psychologically important beyond the functional attributes of the river (for livelihoods, economy, ecology, and recreation). As previously noted, the majority of meanings were shared although there was a potentially significant difference in how the community was defined. Understanding the nuance of the meanings attributed to the affected location can help to pinpoint the precise areas in which people disagree. Identifying shared intangible place meanings can help to reinforce a point of agreement between parties that may strongly diverge in their interests (Nash et al. 2010). Furthermore, our analysis identifies the importance of meanings attributed to the past, which continue into the present and extend into the future. As Nash et al. (2010) suggest, understanding the meanings associated with different points in time can help to identify interventions that bridge the past and future. For example, preserving sites of historical importance, even in different forms, helps to sustain meanings associated with the past, such as was seen in the importance given to the Kings Landing Historical Museum that conserves the predam farming way of life. These interventions are likely to be as important in mitigating the effects of changes to the landscape as those that retain ecosystems, recreation, and the local economy. A shift in debate away from interests and toward place meanings has been found to help the involved parties feel heard and respected and to allow for different issues to be addressed (Cheng et al. 2003, Yung et al. 2003, Wheeler et al. 2016).

Third, mitigation measures may be relatively simple for tangible place meanings that may be lost such as access to recreation, employment (economic meaning), and ecological meanings. In this case, for example, the loss of boating in the headpond by removal of the dam could be compensated by enhancing facilities on other lakes, facilitating a transition to boats that draw less water, or signing deeper channels in the free-flowing river. Impacts on wildlife could be minimized through careful dewatering and active restoration of the exposed land post removal. However, these measures fail to take account of the intangible meanings that would be threatened by the change in biophysical and social 
conditions that result from such a project. These meanings are less easy to compensate or mitigate, deriving as they are from a combination of social and personal factors developed over time. Although the particular method of accounting for intangible meanings will be very context specific, the current situation in this case may be informative. Kings Landing Historical Settlement was widely valued by participants for its preservation of the area's farming culture that existed before the dam was built. Creative solutions such as this should be considered as ways to reduce the impact of disrupted place meanings.

\section{CONCLUSION}

We investigated intangible place meanings attributed in and around a dammed reach of the Saint John River, New Brunswick, Canada, which was the location of a controversial decision around whether to rebuild or remove the dam in question. The participants held a range of intangible meanings and expressed place-based community and personal identities. Many of these meanings were closely linked to the biophysical environment and the experiences and activities that it allows. There were few clear distinctions in intangible meanings between participants who preferred to remove the dam and restore the reach to its natural free-flowing conditions and those who wanted to keep the dam in place. This finding suggests either that tangible meanings, including experiential, economic, and ecological meanings, may be a more significant source of disagreements between stakeholders in this case, or that one difference in community identity meanings between the two groups is highly important. Further studies can distinguish these possible explanations and test the resulting model in a larger sample of the affected population.

\section{Responses to this article can be read online at: http://www.ecologyandsociety.org/issues/responses. php/10811}

\section{Acknowledgments:}

We acknowledge the support of a grant from the Canadian Social Sciences and Humanities Research Council held by Jan Adamowski. We are grateful to all interviewees for their time and participation in this study.

\section{LITERATURE CITED}

Anderson, N. M., K. J. H. Williams, and R. M. Ford. 2013. Community perceptions of plantation forestry: the association between place meanings and social representations of a contentious rural land use. Journal of Environmental Psychology 34:121-136. https://doi.org/10.1016/j.jenvp.2013.02.001

Beckley, T. M., R. C. Stedman, S. M. Wallace, and M. Ambard. 2007. Snapshots of what matters most: using resident-employed photography to articulate attachment to place. Society \& Natural Resources 20(10):913-929. https://doi.org/10.1080/08941920701537007

Bourgoin, S. 2013. Disregarded sentiments: discovering the voices of opposition to the Mactaquac Dam. Thesis. St Mary's University, Halifax, Canada. [online] URL: http://m.library2.smu.ca/ bitstream/handle/01/25269/bourgoin samantha masters 2013.pdf? sequence $=1 \&$ is Allowed $=\mathrm{y}$

Brehm, J. M., B. W. Eisenhauer, and R. C. Stedman. 2013. Environmental concern: examining the role of place meaning and place attachment. Society \& Natural Resources 26(5):522-538. https://doi.org/10.1080/08941920.2012.715726

Brummer, M., B. Rodríguez-Labajos, T. Thanh Nguyen, and D. Jordà-Capdevila. 2017. "They have kidnapped our river": dam removal conflicts in Catalonia and their relation to ecosystem services perceptions. Water Alternatives 10(3):744-768. [online] URL: http://www.water-alternatives.org/index.php/alldoc/articles/ vol10/v10issue 3/380-a10-3-6/file

Buijs, A. E., B. J. M. Arts, B. H. M. Elands, and J. Lengkeek. 2011. Beyond environmental frames: the social representation and cultural resonance of nature in conflicts over a Dutch woodland. Geoforum 42(3):329-341. https://doi.org/10.1016/j.geoforum.2010.12.008

Buijs, A. E., and A. Lawrence. 2013. Emotional conflicts in rational forestry: towards a research agenda for understanding emotions in environmental conflicts. Forest Policy and Economics 33:104-111. https://doi.org/10.1016/j.forpol.2012.09.002

Cheng, A. S., L. E. Kruger, and S. E. Daniels. 2003. "Place" as an integrating concept in natural resource politics: propositions for a social science research agenda. Society \& Natural Resources 16(2):87-104. https://doi.org/10.1080/08941920309199

Davenport, M. A., and D. H. Anderson. 2005. Getting from sense of place to place-based management: an interpretive investigation of place meanings and perceptions of landscape change. Society \& Natural Resources 18(7):625-641. https://doi.org/10.1080/089$\underline{41920590959613}$

Devine-Wright, P. 2009. Rethinking NIMBYism: the role of place attachment and place identity in explaining place-protective action. Journal of Community \& Applied Social Psychology 19 (6):426-441. https://doi.org/10.1002/casp.1004

Devine-Wright, P. 2011. Place attachment and public acceptance of renewable energy: a tidal energy case study. Journal of Environmental Psychology31(4):336-343. https://doi.org/10.1016/ j.jenvp.2011.07.001

Devine-Wright, P. 2013. Explaining "NIMBY" objections to a power line: the role of personal, place attachment and projectrelated factors. Environment and Behavior 45(6):761-781. https:// doi.org/10.1177/0013916512440435

Devine-Wright, P., and Y. Howes. 2010. Disruption to place attachment and the protection of restorative environments: a wind energy case study. Journal of Environmental Psychology 30 (3):271-280. https://doi.org/10.1016/j.jenvp.2010.01.008

Dillon Consulting. 2016. Social impact comparative review. New Brunswick Power Corporation, Fredericton, Canada. [online] URL: https://www.nbpower.com/media/689747/

sicr mactaquac project aug2016.pdf

Doyle, M. W., E. H. Stanley, D. G. Havlick, M. J. Kaiser, G. Steinbach, W. L. Graf, G. E. Galloway, and J. A. Riggsbee. 2008. Aging infrastructure and ecosystem restoration. Science 319 (5861):286-287. http://dx.doi.org/10.1126/science.1149852 
Environmental Systems Research Institute (ESRI). 2016. ArcGIS desktop version 10.4. ESRI, Redlands, California, USA.

Farnum, J., T. Hall, and L. E. Kruger. 2005. Sense of place in natural resource recreation and tourism: an evaluation and assessment of research findings. General Technical Report PNWGTR-660. U.S. Department of Agriculture, Forest Service, Pacific Northwest Research Station, Portland, Oregon, USA. https://doi.org/10.2737/PNW-GTR-660

Gould, R. K., S. C. Klain, N. M. Ardoin, T. Satterfield, U. Woodside, N. Hannahs, G. C. Daily, and K. M. Chan. 2015. A protocol for eliciting nonmaterial values through a cultural ecosystem services frame. Conservation Biology 29(2):575-586. https://doi.org/10.1111/cobi.12407

Gray, B. 2004. Strong opposition: frame-based resistance to collaboration. Journal of Community \& Applied Social Psychology 14(3):166-176. https://doi.org/10.1002/casp.773

Greider, T., and L. Garkovich. 1994. Landscapes: the social construction of nature and the environment. Rural Sociology 59 (1):1-24. https://doi.org/10.1111/j.1549-0831.1994.tb00519.x

Gunderson, K., and A. Watson. 2007. Understanding place meanings on the Bitterroot National Forest, Montana. Society \& Natural Resources 20(8):705-721. https://doi.org/10.1080/08941$\underline{920701420154}$

Jacquet, J. B., and R. C. Stedman. 2014. The risk of socialpsychological disruption as an impact of energy development and environmental change. Journal of Environmental Planning and Management 57(9):1285-1304. https://doi.org/10.1080/09640568.2013 .820174

Johnson, S. E., and B. E. Graber. 2002. Enlisting the social sciences in decisions about dam removal Bioscience 52(8):731-738.

Jorgensen, B. S., and R. C. Stedman. 2001. Sense of place as an attitude: lakeshore owners attitudes toward their properties. Journal of Environmental Psychology 21(3):233-248. https://doi. org/10.1006/jevp.2001.0226

Jorgensen, B. S., and R. C. Stedman. 2006. A comparative analysis of predictors of sense of place dimensions: attachment to, dependence on, and identification with lakeshore properties. Journal of Environmental Management 79(3):316-327. https://doi. org/10.1016/j.jenvman.2005.08.003

Keilty, K., T. M. Beckley, and K. Sherren. 2016. Baselines of acceptability and generational change on the Mactaquac hydroelectric dam headpond (New Brunswick, Canada). Geoforum 75:234-248. https://doi.org/10.1016/j.geoforum.2016.08.001

Kenny, J. L., and A. G. Secord. 2010. Engineering modernity: hydroelectric development in New Brunswick, 1945-1970. Acadiensis 1(1):3-26. [online] URL: https://journals.lib.unb.ca/ index.php/acadiensis/article/view/15382/16519

Kil, N., S. M. Holland, and T. V. Stein. 2014. Place meanings and participatory planning intentions. Society \& Natural Resources 27(5):475-491. https://doi.org/10.1080/08941920.2013.842274

Klain, S. C., and K. M. A. Chan. 2012. Navigating coastal values: participatory mapping of ecosystem services for spatial planning. Ecological Economics 82:104-113. https://doi.org/10.1016/j. ecolecon.2012.07.008
Kyle, G., K. Bricker, A. Graefe, and T. Wickham. 2004. An examination of recreationists' relationships with activities and settings. Leisure Sciences 26(2):123-142. https://doi. org/10.1080/01490400490432019

Lejon, A. G. C., B. M. Renöfält, and C. Nilsson. 2009. Conflicts associated with dam removal in Sweden. Ecology And Society 14 (2):4. https://doi.org/10.5751/ES-02931-140204

Lewicka, M. 2011. Place attachment: How far have we come in the last 40 years? Journal of Environmental Psychology 31 (3):207-230. https://doi.org/10.1016/j.jenvp.2010.10.001

Low, S. M., and I. Altman. 1992. Place attachment: a conceptual inquiry. Pages 1-12 in I. Altman and S. M. Low, editors. Place attachment: human behavior and environment. Springer, Boston, Massachusetts, USA. https://doi.org/10.1007/978-1-4684-8753-4_1

Manzo, L. C. 2003. Beyond house and haven: toward a revisioning of emotional relationships with places. Journal of Environmental Psychology 23(1):47-61. https://doi.org/10.1016/S0272-4944(02) 00074-9

Masterson, V. A., R. C. Stedman, J. Enqvist, M. Tengö, M. Giusti, D. Wahl, and U. Svedin. 2017. The contribution of sense of place to social-ecological systems research: a review and research agenda. Ecology and Society 22(1):49. https://doi.org/10.5751/ ES-08872-220149

Miles, M. B., A. M. Huberman, and J. Saldaña. 2013. Qualitative data analysis: a methods sourcebook. Third edition. Sage, Thousand Oaks, California, USA.

Nash, N., A. Lewis, and C. Green. 2010. 'Not in our front garden': land use conflict, spatial meaning and the politics of naming place. Journal of Community \& Applied Social Psychology 20(1):44-56. https://doi.org/10.1002/casp.1013

NATIONAL and Corporate Research Associates (CRA). 2016. What was said: final report. New Brunswick Power, Fredericton, Canada. [online] URL: https://www.nbpower.com/media/689752/ what was said_report mactaquac.pdf

New Brunswick Power (NB Power). 2016. Considering the future of Mactaquac. New Brunswick Power Corporation, Fredericton, Canada. [online] URL: https://www.nbpower.com/media/693959/ $\underline{\text { mtq-discussion-paper-en.pdf }}$

New Brunswick Power (NB Power). 2017. Backgrounder: Mactaquac Generating Station life achievement project: business case and technical considerations. NB Power, Fredericton, Canada. [online] URL: https://www.nbpower.com/media/693949/ backgrounder-mtq-business-and-technical-en.pdf

Patton, M. Q. 2005. Qualitative research. Pages 1633-1636 in B. S. Everitt and D. C. Howell, editors. Encyclopedia of statistics in behavioral science. Wiley, Chichester, UK. https://doi. org/10.1002/0470013192.bsa514

Perlaviciute, G., and L. Steg. 2014. Contextual and psychological factors shaping evaluations and acceptability of energy alternatives: integrated review and research agenda. Renewable and Sustainable Energy Reviews 35:361-381. https://doi. org/10.1016/j.rser.2014.04.003

Reilly, K. H., and J. F. Adamowski. 2017a. Stakeholders' frames and ecosystem service use in the context of a debate over 
rebuilding or removing a dam in New Brunswick, Canada. Ecology and Society 22(1):17. https://doi.org/10.5751/ES-09045-220117

Reilly, K. H., and J. F. Adamowski. 2017b. Spatial and temporal scale framing of a decision on the future of the Mactaquac Dam in New Brunswick, Canada. Ecology and Society 22(3):21. https:// doi.org/10.5751/ES-09535-220321

Reilly, K., J. Adamowski, and K. John. 2018. Participatory mapping of ecosystem services to understand stakeholders' perceptions of the future of the Mactaquac Dam, Canada. Ecosystem Services 30(A):107-123. https://doi.org/10.1016/j. ecoser.2018.01.002

Rickard, L. N., and R. C. Stedman. 2015. From ranger talks to radio stations: the role of communication in sense of place. Journal of Leisure Research 47(1):15-33. https://doi. org/10.1080/00222216.2015.11950349

Sandström, C., K. Eckerberg, and K. Raitio. 2013. Studying conflicts, proposing solutions - towards multi-level approaches to the analyses of forest conflicts. Forest Policy and Economics 33:123-127. https://doi.org/10.1016/j.forpol.2013.05.002

Sherren, K., T. M. Beckley, J. R. Parkins, R. C. Stedman, K. Keilty, and I. Morin. 2016. Learning (or living) to love the landscapes of hydroelectricity in Canada: eliciting local perspectives on the Mactaquac Dam via headpond boat tours. Energy Research \& Social Science 14:102-110. https://doi.org/10.1016/j.erss.2016.02.003

Si, Z. 1993. A theoretical framework for social impact analysis with special reference to population relocation at the Mactaquac Dam project on the Saint John River. Thesis. Dalhousie University, Halifax, Canada. [online] URL: http://hdl.handle.net/10222/55366

Sidaway, R. 2005. Resolving environmental disputes: from conflict to consensus. Routledge, London, UK. https://doi. org/10.4324/9781849772372

Smaldone, D., C. Harris, and N. Sanyal. 2008. The role of time in developing place meanings. Journal of Leisure Research 40 (4):479-504. https://doi.org/10.1080/00222216.2008.11950149

Smith, J. W., M. A. Davenport, D. H. Anderson, and J. E. Leahy. 2011. Place meanings and desired management outcomes. Landscape and Urban Planning 101(4):359-370. https://doi. org/10.1016/j.landurbplan.2011.03.002

Stanley, E. H., and M. W. Doyle. 2003. Trading off: the ecological effects of dam removal. Frontiers in Ecology and the Environment 1(1):15-22. https://doi.org/10.1890/1540-9295(2003)001[0015:TOTEEO] 2.0.CO:2

Stantec. 2016. Mactaquac project comparative environmental review report. Stantec, Fredericton, Canada. [online] URL: https://www.nbpower.com/media/689743/cer mactaquac project summary document aug2016.pdf

Stedman, R. C. 2002. Toward a social psychology of place: predicting behavior from place-based cognitions, attitude, and identity. Environment and Behavior 34(5):561-581. https://doi. org/10.1177/0013916502034005001

Stedman, R. C. 2003. Is it really just a social construction?: The contribution of the physical environment to sense of place. Society \& Natural Resources 16(8):671-685. https://doi. org/10.1080/08941920309189
Stedman, R. C. 2008. What do we "mean" by place meanings? Implications of place meanings for managers and practitioners. Pages 61-82 in L. E. Kruger, T. E. Hall, and M. C. Stiefel, editors. Understanding concepts of place in recreation research and management. General Technical Report PNW-GTR-744. U.S. Department of Agriculture, Forest Service, Pacific Northwest Research Station, Portland, Oregon, USA. https://doi. org/10.2737/PNW-GTR-744

Stedman, R. C. 2016. Subjectivity and social-ecological systems: a rigidity trap (and sense of place as a way out). Sustainability Science 11(6):891-901. https://doi.org/10.1007/s11625-016-0388y

Stedman, R. C., T. Beckley, S. Wallace, and M. Ambard. 2004. A picture and 1000 words: using resident-employed photography to understand attachment to high amenity places. Journal of Leisure Research 36(4):580-606. https://doi.org/10.1080/00222216.2004.11950037

Stokowski, P. A. 2002. Languages of place and discourses of power: constructing new senses of place. Journal of Leisure Research 34(4):368-382. https://doi.org/10.1080/00222216.2002.11949977

Strauss, A., and J. Corbin. 1998. Basics of qualitative research: techniques and procedures for developing grounded theory. Second edition. Sage, Thousand Oaks, California, USA.

Tonitto, C., and S. J. Riha. 2016. Planning and implementing small dam removals: lessons learned from dam removals across the eastern United States. Sustainable Water Resources Management 2(4):489-507. https://doi.org/10.1007/s40899-016-0062-7

Tuan, Y.-F. 1977. Space and place: the perspective of experience. University of Minnesota Press, Minneapolis, Minnesota, USA.

Vorkinn, M., and H. Riese. 2001. Environmental concern in a local context: the significance of place attachment. Environment and Behavior 33(2):249-263. https://doi.org/10.1177/00139160121972972

Wester-Herber, M. 2004. Underlying concerns in land-use conflicts - the role of place-identity in risk perception. Environmental Science \& Policy 7(2):109-116. https://doi. org/10.1016/j.envsci.2003.12.001

Wheeler, M. J., A. J. Sinclair, P. Fitzpatrick, A. P. Diduck, and I. J. Davidson-Hunt. 2016. Place-based inquiry's potential for encouraging public participation: stories from the common ground land in Kenora, Ontario. Society \& Natural Resources 29 (10):1230-1245. https://doi.org/10.1080/08941920.2015.1122130

Williams, D. R. 2008. Pluralities of place: a user's guide to place concepts, theories, and philosophies in natural resource management. Pages 7-30 in L. E. Kruger, T. E. Hall, and M. C. Stiefel, editors. Understanding concepts of place in recreation research and management. General Technical Report PNWGTR-744. U.S. Department of Agriculture, Forest Service, Pacific Northwest Research Station, Portland, Oregon, USA. https://doi.org/10.2737/PNW-GTR-744

Williams, D. R., and M. E. Patterson. 1996. Environmental meaning and ecosystem management: perspectives from environmental psychology and human geography. Society \& Natural Resources 9(5):507-521. https://doi.org/10.1080/08941929609380990

Williams, D. R., and M. E. Patterson. 1999. Environmental psychology: mapping landscape meanings for ecosystem 
management. Pages 141-160 in H. K. Cordell and J. C. Bergstrom, editors. Integrating social sciences with ecosystem management. Sagamore Press, Champaign, Illinois, USA. [online] URL: https://www.fs.usda.gov/treesearch/pubs/29423

Wondolleck, J. M., B. Gray, and T. Bryan. 2003. Us versus them: how identities and characterizations influence conflict. Environmental Practice 5(3):207-213. https://doi.org/10.1017/ $\underline{\mathrm{S} 1466046603035592}$

Yung, L., W. A. Freimund, and J. M. Belsky. 2003. The politics of place: understanding meaning, common ground, and political differnce on the Rocky Mountain front. Forest Science 49 (6):855-866. https://doi.org/10.1093/forestscience/49.6.855 


\section{Appendix 1}

Interview protocol

The purpose of the study was explained to participants, along with confidentiality procedures, and consent was requested.

Section 1: General questions

For new participants:

- Are you aware of the process to decide what should happen to the Mactaquac Dam when it reaches the end of its life? (Show pictures of the three options if necessary.)

- What do you think should happen to it?

- What are your reasons for that?

- How do you think removing the dam would affect you?

- And rebuilding it?

- Have you read any of the information that New Brunswick Power has published about the decision on the dam?

- Have you participated in any of the consultation activities they've been doing, like the meetings, the online comments, etc.?

For returning participants:

- Have you read any of the information that NB Power has published about the decision on the dam?

- Have you participated in any of the consultation activities they've been doing, like the meetings, the online comments, etc.?

- I'm going to ask you the same question again that I asked you last time: what do you think should happen to the dam?

- What are your reasons for that?

Section 2: Ecosystem services and place meanings

Personal - general

- Now we're going to think about how you use places around the river in your personal life.

- What are the places that you use most or that are particularly important to you on the map? Think about all the seasons as well, not just where you use in summer.

- Can you tell me what you do at place number [x]? And what is it about that place that you like? What's important about it? Are there any other reasons that you go to that place in particular? How often do you go there?

- Now we're going to go through some more specific questions to see if there are any other places you'd like to add. It's ok if some of these questions make you think of places you've already drawn, just point out the number to me. It's also fine if as we're going through the questions you think of a place that answers a previous question just draw it and then we'll talk about it.

Personal - recreation, relaxation and wellbeing

- Are there any other activities that you do or experiences that you have around the river that we've missed? 
- What is it about [doing activity/having that experiences] in those particular places that you like? What's important about those places? Are there any other reasons that you go to that place in particular? How often do you go there?

Personal - non-use values

- Now I'd like you to think about any other places that you think are important but not because of anything that you directly or personally you get from them (Gould et al., 2015).

- Why are those places important?

Personal - identity and social and community connections

- Now if we think about a person's identity, it comes from their relationships, ideas, sense of belonging, and all these shape who they are (Gould et al., 2015; Klain and Chan, 2012).

- Are there any places that are important for your sense of identity? How would you describe the link between that place and your identity (Gould et al., 2015; Klain and Chan, 2012)?

Personal - heritage and memories

- Are there places that remind of you of things that happened in the past that were important for you or for your community (Gould et al., 2015; Klain and Chan, 2012)?

Personal - intergenerational/bequest

- Are there any places or experiences in and around the river that you hope that your kids or the kids around here will experience in the future (Gould et al., 2015; Klain and Chan, 2012)?

- What is it about those places that you hope they will experience?

Personal - provisioning

- I'd like you to think about if you get any physical things, like resources, food or materials from in and around the river in your work or personal life. I mean here things that you're involved in getting for yourself. Your water supply wouldn't count unless you personally are involved in collecting water.

- If you haven't already, can you draw any of the places that you get those things from? What do you get at each place? How often do you go there to get those things?

- Is it important to you to be able to get those things yourself? How?

Personal - movement

- Do you use the river to get around? Where do you go? Can you describe the difference between using the river for that and using a different way to get around, like by car? How often do you do that?

Regulating - flood control and water quality

- Are there places that you think are important for your environment more generally, like for maintaining water quality, flood control, and soil fertility? 


\section{Appendix 2}

Codebook for intangible meanings

\begin{tabular}{|c|c|c|}
\hline Code/dimension & Category & Example \\
\hline Attachment to water & Personal identity & $\begin{array}{l}\text { 'As a little boy I was very close to the river, and for some } \\
\text { reason it just kind of gets embedded in you.' }\end{array}$ \\
\hline Belonging & Personal identity & $\begin{array}{l}\text { 'When I first came in sight of the St John up around } \\
\text { Hartland, just all of a sudden I felt, I felt where I belonged } \\
\text { again' }\end{array}$ \\
\hline Celebrations & Community identity & $\begin{array}{l}\text { 'What happens is when the ice breaks and comes down } \\
\text { and jams, and then there's just this crunching and } \\
\text { moving, and it can get really loud. I mean, it's really } \\
\text { amazing. And so there's sort of a community ceremony, } \\
\text { sort of community ritual' }\end{array}$ \\
\hline Childhood memories & Personal identity & $\begin{array}{l}\text { 'Growing up we canoed, kayaked, motorboated. Just, that } \\
\text { was, we'd play on the water, it was part of the backyard' }\end{array}$ \\
\hline $\begin{array}{l}\text { Community Connection/ } \\
\text { Reduced Isolation }\end{array}$ & Community identity & $\begin{array}{l}\text { 'It's recreational yes, but it's also a main throughfare to } \\
\text { get to, community to community is right, so you're not } \\
\text { isolated in this area' }\end{array}$ \\
\hline Community History & Community identity & $\begin{array}{l}\text { 'The [name] was put together by a number of people who } \\
\text { are interested in seeing Kings Landing continue and } \\
\text { flourish for generations to come. Because the older it is, } \\
\text { the more important it is for people to look back on.' }\end{array}$ \\
\hline Community Relationships & Community identity & $\begin{array}{l}\text { 'Used to be I knew everybody from here to Fredericton. } \\
25 \text { miles that way. And to Woodstock, which is } 30 \text { miles } \\
\text { that way. Because they were all farmers.' }\end{array}$ \\
\hline Cultural activity & Community identity & $\begin{array}{l}\text { 'Fiddleheads is something that you know, we New } \\
\text { Brunswickers we harvest them. A lot of places don't, } \\
\text { even where they grow, I don't think they even harvest } \\
\text { them' }\end{array}$ \\
\hline Didn't grow up here & Personal identity & $\begin{array}{l}\text { 'I never lived there in the past. Yeah. We're transplants. } \\
\text { So I have no connection to what the river used to be' }\end{array}$ \\
\hline Familiarity & Personal identity & $\begin{array}{l}\text { 'You know, there's a magic about that river and knowing } \\
\text { where to fish and knowing where the rocks are' }\end{array}$ \\
\hline Family ancestry & Community identity & $\begin{array}{l}\text { 'We migrated and came up the Saint John River valley. } \\
\text { And the King of England promised us land, and we got } \\
\text { land. So here we are. We're still here' }\end{array}$ \\
\hline Family relationships & Community identity & $\begin{array}{l}\text { 'At Thanksgiving we always go picking apples with the } \\
\text { kids who are now thirty-something. My daughter's } \\
\text { coming back for thanksgiving this year, so we'll pick } \\
\text { apples. And there's apples at a beautiful place.' }\end{array}$ \\
\hline First nature experiences & Personal identity & $\begin{array}{l}\text { 'There are kids like my nephews, my great nephews, the } \\
\text { one who was here Saturday and the others who've been } \\
\text { here before, who would never get out on this river in a } \\
\text { boat with our marina gone.' }\end{array}$ \\
\hline
\end{tabular}




\begin{tabular}{|c|c|c|}
\hline Code/dimension & Category & Example \\
\hline Fishery history & Community identity & $\begin{array}{l}\text { 'We've lost the salmon population in the river. And that's } \\
\text { directly because of two dams, not just Mactaquac but, you } \\
\text { know. Or three dams. Yeah. so I think we need to do } \\
\text { more to protect the fishery and the history of the river.' }\end{array}$ \\
\hline Friend relationships & Community identity & $\begin{array}{l}\text { 'It's a social gathering. It's a protected creek and I think } \\
\text { that if, on a weekend there's all kinds of boats in there' }\end{array}$ \\
\hline Fulfilment & Personal identity & $\begin{array}{l}\text { 'For me, I get more of my energy and fulfilment from } \\
\text { being around things in nature' }\end{array}$ \\
\hline Grew up here & Personal identity & $\begin{array}{l}\text { 'I grew up right along the Mactaquac headpond. I was } \\
\text { born in 1961, the dam was built in 1967. I stuck my feet } \\
\text { in it every summer, and it's just part of my lifestyle' }\end{array}$ \\
\hline Had to leave for work & Personal identity & 'I would go away and work places but I'd come back.' \\
\hline Home & Personal identity & $\begin{array}{l}\text { 'I missed the river. I used to sit and try to think why I felt } \\
\text { so homesick. I missed my folks but I missed the river' }\end{array}$ \\
\hline Houses on river & Personal identity & $\begin{array}{l}\text { 'I know a lot of people who live up here and I would } \\
\text { certainly sympathise with them. It's a tough decision. } \\
\text { You know, when you build up in a place like that, That's } \\
\text { the risk you take.' }\end{array}$ \\
\hline I'm part of a bigger system & personal identity & $\begin{array}{l}\text { 'That stream goes over the falls and goes right down to } \\
\text { this pond of water and out into the river. And away to the } \\
\text { sea. And I like the, I don't know, there's something about } \\
\text { the continuity of that thought that I like.' }\end{array}$ \\
\hline Industry legacies & Community identity & $\begin{array}{l}\text { 'They cut them all down. Or most of them. The only ones } \\
\text { left are not on crown land. Out through this Pokiok } \\
\text { country, they devastated it.' }\end{array}$ \\
\hline Intimacy with river & Personal identity & $\begin{array}{l}\text { 'You lose the islands and you lose the intimacy of the } \\
\text { smaller river, the smaller body of water, the current kind } \\
\text { of pushing you along' }\end{array}$ \\
\hline Joy & Personal identity & $\begin{array}{l}\text { 'It's the coldest, bleakest day of winter, and then I see a } \\
\text { little chickadee or a troop of chickadees, and they're so } \\
\text { energetic and they're happy to be out and it's - } 40 \text { and } \\
\text { they don't care. And you know I'm shivering away and } \\
\text { then, it just makes me feel better about myself and better } \\
\text { to be part of the world because there are other things that } \\
\text { are there that seem to invoke a sense of joy' }\end{array}$ \\
\hline Learning & Community identity & $\begin{array}{l}\text { 'We take our grandsons there when we can, for the simple } \\
\text { fact that they can go there and they can touch an animal } \\
\text { and they can. And if we can keep them quiet enough, you } \\
\text { know they can watch people make butter. They can see } \\
\text { how people dressed. They can see that people, there's a } \\
\text { piece of history that they can visualise that you can't get } \\
\text { from your history teacher' }\end{array}$ \\
\hline Leave things for kids & Community identity & $\begin{array}{l}\text { '...but what we're hoping is that our grandsons will go } \\
\text { there sometime when they get older and have that as a } \\
\text { camping spot or whatever' }\end{array}$ \\
\hline
\end{tabular}




\begin{tabular}{|c|c|c|}
\hline Code/dimension & Category & Example \\
\hline Life's work & Personal identity & $\begin{array}{l}\text { 'My husband said that when I die he's going to have me } \\
\text { cremated and sprinkle the ashes at [name]. Because I've } \\
\text { never left it since I was 19!' }\end{array}$ \\
\hline Maintains community & Community identity & $\begin{array}{l}\text { 'All that area's been settled by a lot of people that have } \\
\text { worked and do work at Mactaquac Dam. So, so, you'd be } \\
\text { losing, you'd be destroying quite a community.' }\end{array}$ \\
\hline Maliseet culture & Community identity & $\begin{array}{l}\text { 'Which marks the Meductic Fort, which was, which was a } \\
\text { settlement of the Maliseet people of great historic and } \\
\text { prehistoric significance.' }\end{array}$ \\
\hline Maliseet sacred lands & Community identity & $\begin{array}{l}\text { 'Hawk Island up here, 5B where we fiddlehead, that was } \\
\text { the meeting place of all the Maliseets that were, you } \\
\text { know, all the tribes that were, you know, covered the } \\
\text { Acadia area. That's where they met in the summertime. } \\
\text { And everybody was allotted their, you know, the areas } \\
\text { that each tribe is going to hunt' }\end{array}$ \\
\hline Memories as adults & Personal identity & $\begin{array}{l}\text { 'Every place where I have encountered something } \\
\text { interesting in nature, I recall. So when I go back to that } \\
\text { place, I think, oh ten years ago or } 20 \text { years ago, I saw } \\
\text { such and such here and I wonder if I'll ever see it again. } \\
\text { So, I can't go anywhere without getting that kind of } \\
\text { memory evoked.' }\end{array}$ \\
\hline My land & Personal identity & $\begin{array}{l}\text { 'When the dam came up the government bought all of the } \\
\text { rest of the farm. But there was a small parcel there that } \\
\text { they didn't take. And a lot of what they did take was sold } \\
\text { back to people other than ourselves. But that's important } \\
\text { because we own a small piece of the old farm.' }\end{array}$ \\
\hline My spot & Personal identity & $\begin{array}{l}\text { 'And so many things that I value, more than any other } \\
\text { place on the planet, happened for me right in this area, of } \\
\text { course. So this stream, and that pond, and the falls. Very } \\
\text { important to me' }\end{array}$ \\
\hline $\begin{array}{l}\text { Nature as community } \\
\text { heritage }\end{array}$ & Community identity & $\begin{array}{l}\text { 'If there's a sense of a need to conserve anything within a } \\
\text { particular community I think it's going to often be the } \\
\text { perhaps the most significant or important natural feature } \\
\text { within that community' }\end{array}$ \\
\hline Neighbour relationships & Community identity & $\begin{array}{l}\text { 'I live on a street with } 15 \text { houses, or } 12 \text { houses and } 18 \\
\text { kids under five. So there's lots of good neighbours and } \\
\text { things like that. So it's interesting.' }\end{array}$ \\
\hline $\begin{array}{l}\text { No identity because not } \\
\text { indigenous }\end{array}$ & Personal identity & $\begin{array}{l}\text { 'If I understand the question no. I'm not a native or } \\
\text { anything' }\end{array}$ \\
\hline No identity with headpond & Personal identity & $\begin{array}{l}\text { 'The dam's obviously a reference point as you're } \\
\text { travelling along the TransCanada highway. But as far as } \\
\text { would I send somebody to go see this or go see that, } \\
\text { something that I would identify with, nope.' }\end{array}$ \\
\hline Nostalgia & Personal identity & $\begin{array}{l}\text { 'This would be my mother-in-law's farm. At number } 4 . \\
\text { And that has a lot of, if you want to... sentimental, } \\
\text { nostalgic value to my wife and to our children as well.' }\end{array}$ \\
\hline
\end{tabular}




\begin{tabular}{|c|c|c|}
\hline Code/dimension & Category & Example \\
\hline Notable/selling point & Community identity & $\begin{array}{l}\text { "When I travel, to find a place that is as nice as our } \\
\text { walking trail, and to be able to take advantage of it, I } \\
\text { would have thought "oh my gosh, I found a treasure } \\
\text { here!"" }\end{array}$ \\
\hline Part of life & Personal identity & $\begin{array}{l}\text { 'The river runs through me. It, I don't know. My life's } \\
\text { just tied to it' }\end{array}$ \\
\hline Part of me & Personal identity & $\begin{array}{l}\text { 'As a little boy I was very close to the river, and for some } \\
\text { reason it just kind of gets embedded in you' }\end{array}$ \\
\hline Partner relationship & Personal identity & $\begin{array}{l}\text { 'I didn't learn to fish until I met my husband. And now I } \\
\text { love it.' }\end{array}$ \\
\hline Peaceful & Personal identity & $\begin{array}{l}\text { 'When I'm out in my boat by myself, especially by } \\
\text { myself, I find it's like therapy. I just get so excited and } \\
\text { when I get out there it's like this sense of relief. And I } \\
\text { don't know I just love the peacefulness.' }\end{array}$ \\
\hline Personal accomplishment & Personal identity & $\begin{array}{l}\text { 'There's a little plant called the prototype quillwort, } \\
\text { which was a species I helped describe as new to science } \\
\text { about } 15 \text { years ago.' }\end{array}$ \\
\hline $\begin{array}{l}\text { Proud of what we've done } \\
\text { here }\end{array}$ & Community identity & $\begin{array}{l}\text { 'I don't want people from other areas coming here and } \\
\text { sort of justifiably criticising us for things we've done. I } \\
\text { like to be proud it. So you know whatever we do here, I } \\
\text { hope I can be proud of that' }\end{array}$ \\
\hline Relaxed & Personal identity & $\begin{array}{l}\text { 'It's a stress reliever right there. When you run three } \\
\text { businesses, it's... it's nice. Talk about something else, } \\
\text { have some thoughts of your own.' }\end{array}$ \\
\hline $\begin{array}{l}\text { Remember what it was } \\
\text { like }\end{array}$ & Personal identity & $\begin{array}{l}\text { 'Keep in mind that those that have been around post dam, } \\
\text { particularly those that front the river and look at it, who } \\
\text { can't remember the beauty of a free-flowing river you } \\
\text { know may have their own commitment to the current } \\
\text { status quo' }\end{array}$ \\
\hline $\begin{array}{l}\text { Retain connection to } \\
\text { previous generations }\end{array}$ & Community identity & $\begin{array}{l}\text { 'I come from an old farm family that's farm was over in } \\
\text { Devon there, the old farm. And I, I never worked on that } \\
\text { farm. My, my ancestors come from there, and they used } \\
\text { to, they used to actually graze their cattle down there in } \\
\text { the summertime' }\end{array}$ \\
\hline River culture & Community identity & $\begin{array}{l}\text { 'It seems to me that the river itself has a certain aspect } \\
\text { that arguably there would be no New Brunswick without } \\
\text { the St John River.' }\end{array}$ \\
\hline River history & Community identity & $\begin{array}{l}\text { 'We are of a different time, a different generation, and a } \\
\text { different product. But this river's been here forever. } \\
\text { Long, long time. Nope. And who the hell are we to mess } \\
\text { it up' }\end{array}$ \\
\hline Show visitors & Community identity & $\begin{array}{l}\text { 'I just recently took a new family to Canada down to the } \\
\text { campground and the girls went ballistic over the beach, } \\
\text { you know. And being able to run in the water' }\end{array}$ \\
\hline Socialising with strangers & Community identity & $\begin{array}{l}\text { 'There's a total social network. When you're, when } \\
\text { you're out there in a boat you're meeting totally different } \\
\text { people in the community.' }\end{array}$ \\
\hline Source of art & Personal identity & $\begin{array}{l}\text { 'And, and so a lot of my [art] has been about water and } \\
\text { rivers.' }\end{array}$ \\
\hline
\end{tabular}




\begin{tabular}{|c|c|c|}
\hline Code/dimension & Category & Example \\
\hline Stands out/unique & Community identity & $\begin{array}{l}\text { 'So you can walk right from that convention centre and } \\
\text { right there, mark that number } 4 \text {, you can catch any one of } \\
\text { ten species of fish and you can take those fish home, back } \\
\text { to the convention centre and have them cook them and eat } \\
\text { them for dinner. And that's a very special, that's a } \\
\text { different kind of city' }\end{array}$ \\
\hline Taken for granted & Community identity & $\begin{array}{l}\text { 'They're undervalued by people who take them for } \\
\text { granted because people live here all the time.' }\end{array}$ \\
\hline What I know & Personal identity & $\begin{array}{l}\text { 'I came here to this country in } 83 \text { and it was built in } 64 \text { or } \\
\text { something. So, like I don't know any different' }\end{array}$ \\
\hline $\begin{array}{l}\text { What it means to be from } \\
\text { here }\end{array}$ & Personal identity & $\begin{array}{l}\text { 'I think the river basically from the dam down has been, } \\
\text { is what I really associate and really relate to as far as } \\
\text { being from, Fredericton is and what it means to be, you } \\
\text { know, situated on this beautiful river.' }\end{array}$ \\
\hline Why we live here & Personal identity & $\begin{array}{l}\text { 'I always wanted to live here. I guess I've always enjoyed } \\
\text { nature and being at the woods or being at the water' }\end{array}$ \\
\hline Will travel to be here & Personal identity & $\begin{array}{l}\text { 'My family's chosen to work out west and make the } \\
\text { money, but make their house and life in the Mactaquac } \\
\text { area' }\end{array}$ \\
\hline Wonder & Personal identity & $\begin{array}{l}\text { What I'd really love to see is that each child have the } \\
\text { opportunity to experience something in this river valley } \\
\text { that shapes their life forever. And that they never forget } \\
\text { that.' }\end{array}$ \\
\hline
\end{tabular}

